\title{
Factors Affecting the Market Share of Retailers: Evidence from Vietnam
}

\author{
Hung Cuong PHAM ${ }^{1}$
}

Received: February 05, 2020 Revised: September 19, 2020 Accepted: October 05, 2020

\begin{abstract}
This research focuses on the analysis of factors affecting the market share of retailers in Vietnam. This research uses Smith and Chaffey's (2005) 5Ss e-marketing model for analysis, which include Sell, Serve, Speak, Save, and Sizzle. Both quantitative and qualitative methods will be used to conduct the study. The researchers collected information from customers, managers, and directors in 25 retailers in Vietnam. A survey questionnaire was delivered to 15 people in each of the retailers who are customers, managers and directors. The researcher used the SPSS 16.0 software to analyze the data collected and in-depth interviews were carried out with the purpose of testing the hypothesis as well as the overall framework of the research. Out of the 375 questionnaires delivered, 360 were returned. The means of 23 items in the survey questionnaire ranged from 3.3733 to 4.3533 representing the outcome of the descriptive analysis. Research results showed that Cronbach's Alpha coefficient of five factors affecting the market share of the retailers is sizzle, save, sell, serve and speak. This research has proposed some implications for the market share of retailers, including technology enhancement for full message delivery, ways to approach target customers, and improving product diversity.
\end{abstract}

Keywords: E-Marketing, Market Share, Online Retailer

JEL Classification Code: M1, L81

\section{Introduction}

Gaining market share is among the top concerns of any business. The reason is that market share serves as a primary base to attract customers from whom companies can generate its income and profits. By applying more tools, which are closely related to and familiar with customers like Internet and information graphics delivery, many companies start to enjoy the fruits of their efforts with limited budget and in a very short period of time. It is of great importance to be aware that there are plenty of e-tools that designers and marketers could use in order to draw customers' attention and emotionally engage them for action. In Vietnam, the market economy was recognized at the end of 1986 under the revolution all "Reform". Later on, by 1995, the Internet started its life, much later than in other parts of the world.

${ }^{1}$ First Author and Corresponding Author. Manager, Scientific Management and International Cooperation Department, Foreign Trade University, Ho Chi Minh City Campus, Vietnam [Postal Address: 15D5, Ward 25, Binh Thanh District, Ho Chi Minh City, 700000, Vietnam] Email: phamhungcuong.cs2@ftu.edu.vn

(C) Copyright: The Author(s)

This is an Open Access article distributed under the terms of the Creative Commons Attribution Non-Commercial License (https://creativecommons.org/licenses/by-nc/4.0/) which permits unrestricted non-commercial use, distribution, and reproduction in any medium, provided the original work is properly cited.
As a result, e-marketing or e-commerce has not enjoyed an outstanding development until recently, around 2012.

For the retailing sector, especially supermarket retailing, the small market scale of Vietnam in comparison with markets in the region somehow restricts its full growth and makes it difficult to attract serious investment. However, there are basic elements for a potential development in Vietnam such as: big population of mainly young people, high rate of economic potential, speedy infrastructure development, business environment improvement, and non-stop improvement of living standard. All of these factors would strongly support the coming stage of development in retailing market, which, in Vietnam, has been recognized as having enormous potential.

In Vietnam, especially in big key cities like Ho Chi Minh City, there is a big competition between domestic players like Co-op mart, Citimart, Maximart, and international retailing groups like Metro Cash and Carry, Lotte, Big C and others. The competition is even getting stronger when small shopping store chains are now mushrooming, like Shop and Go, B's mart, Circle K, to name a few. These retailers are trying their best to build as big a market share as possible. All the retailers in Vietnam nowadays have to face a fierce competition in the retailing market. The competition not only comes from local supermarkets, but also from foreign ones. How to increase the market share of each retailer in this condition has been a rather difficult mathematic matter for nearly all managers. 


\section{Literature Review}

\subsection{Internet Marketing}

Internet marketing is a part of business representing lots of opportunities (Chaffy, 2008) when customer wants to order products or services, they have a wide selection to choose from. According to Kotler (2005) "The internet will create the new winners and burry the laggard". Network marketing is one of the very important tools to improve business. In Internet marketing, it is especially beneficial to use social media. Social media are used by everyone and, as the owner of a company; no one would like to fall behind their competitors. There are basically four reasons to use social media as a marketing tool: communication, education, collaboration, and entertainment. Internet marketing provides an effective medium for directly communicating with customers by initiating the conversation yourself.

With the support of search engines, the distance between brands and customers are getting closer and the interaction becomes more frequent. The complicated relationship that involves all components of the variable outlines a positive and significant effect, except for the path of analysis (Firman et al., 2020). The antecedents of relationship marketing positively effect customer relationship and customer loyalty. Moreover, customer relationship has a positive impact on customer loyalty when shopping for fashion products (Khoa, 2020). Besides, Internet marketing could take advantage of words, motions, technology and the refined combination of colors and sounds to educate a large portion of perspective customers about the company, its missions/core value and its services/products.

Furthermore, the collaboration between multiple websites does increase the brand awareness by expanding the banner and clicks from different sources. Four factors that influence positively customer satisfaction regarding the quality of online services in Tiki.vn e-commerce platform in descending strength are: trust, customer service, web design, and safety. In addition, the results show no difference in customer satisfaction according to academic levels, but in terms of occupation and income, gender, and age. The results show that the factors influencing most customer satisfaction are reliability and customer service (Giao, 2020).

Finally, to create special interest in the company, Internet marketing could provide many tools to satisfy potential customers with exciting entertaining visual and audio effect. Marketing is defined as a social and managerial process by which individuals and groups obtain what they need and want through creating and exchanging products and value with others. It is the process by which companies create value for customers and build strong customer relationships in order to capture value from customers in return. Electronic marketing is the marketing side of e-commerce - company efforts to communicate about, promote and sell products and services over the Internet. The determinants that influence the acceptance of eWOM information are informational factors and factors related to consumer skepticism (Dinh et al., 2020). Product risk, convenience risk, and return policy risk have a significant and positive impact on online shopping behavior. Financial risk is found to have insignificant and negative effects on consumer behavior.

In addition, the non-delivery risk is found to have a significant and negative impact on online shopping behavior (Tham et al., 2019). Perceived usefulness has a positive effect on attitude and intention to use the service. Therefore, it is necessary to enhance the sense of usefulness to customers through media advertising and consulting so that customers fully understand the benefits brought about by using digital banking services (Nguyen, 2020). Perceived usefulness has a positive effect on attitude and intention to use the service. Reliability as a dimension of e-retailing of Islamic banks made a significant impact on customers' overall satisfaction; there is a positive significant relationship between responsiveness and customers' overall satisfaction and there is a positive impact of good e-service on customers' satisfaction, but it does not override unsatisfactory performance in other areas (Tabash et al., 2019).

\subsection{E-marketing Models}

For the field of e-marketing, there are different models defined by different researchers and economists, for example: 4 Pillar E-marketing by Surjanovic and Varagic (2003), SOSTA by Smith and Chaffey (2005), and 5Ss of E-marketing by Smith and Chaffey (2005). 4 Pillars E-marketing is considered to be the most effective Internet marketing technology and tactics based on the needs of customers in particular. This model is used to link the direct response effects of a concrete e-marketing strategy with the factors of online branding strategy. This model can be used as a bridge between direct response strategy and online branding strategy.

Another name for 4 Pillars E-marketing is $4 \mathrm{C}$ e-marketing strategy, which can be defined as: (1) Content: each website has its own unique content, which facilitates direct and indirect effects of the organization's online image and presence. The unique selling point (USP) of each website is the key success to its original concept where the content fulfills the online goals. (2) Click Stream: it is the observation of all users' activities when users enter or visit the website, such as where is the consumer from? What is his/her gender?, etc. Click Stream helps improve the interaction in the website effectively. The precise analysis of users behavior on the website represents the strongest weapon of an online presence. (3) Communication: users can have a chat or communication with the administrator of the website to get the information they need. Chat functionality and other communication tools are able to magnify the most wanted response on the website. (4) Conversion: Using effectively the first three pillars of Internet marketing strategy, the result should be better direct effects (the conversion from visitors to customers). The goal 
of this online strategy element is to additionally improve the website conversion. SOSTA is the popular planning model developed in the 1990s to make plans for different activities.

The analysis on marketplace SWOT including 5S's performance and other KPIs, customer insight, market trends, competitor, internal capabilities and resources. Objectives - where do we want to be? Determination of 5S's objectives including Sell (customer acquisition and retention targets), Serve (customer satisfaction targets), Sizzle (the added value), Speak (engaging customers) and Save (quantified efficiency). Strategy - how do we get there? After stating objectives for the plan, STOPS (segments, target markets, objectives, positioning) and SIT (sequence, integration, targeting and segmentation) are elements that need to be analyzed. Tactics - how exactly do we get there? Consideration of marketing mix (8Ps, including communication mix, content plan, contact plan). Actions - the details of tactics. Determination of who does what and when (responsibilities and structures, processes and systems, internal resources and skills, external agencies). In general, companies need and develop e-marketing because of different purposes, Smith and Chaffey (2005) designed the 5Ss e-marketing model, which identifies five outstanding benefits or reasons for applying e-marketing into the business that marketers can utilize to set up their business goals.

\section{Research Method}

\subsection{Research Framework}

The research uses the e-marketing model formulated by Smith and Chaffey (2005), which is called 5Ss E-marketing model. The 5Ss includes Sell, Serve, Speak, Save and Sizzle. These $5 \mathrm{Ss}$ affects the market share of retailers in the market (Figure 1).

In this paper, the researcher uses both quantitative and qualitative approaches to collect and analyze the data. According to Cooper and Schindler (2006) and Kuhn (1961), quantitative methodologies are used to measure consumer behaviors, knowledge, opinions, or attitudes in most business research. Denzin and Lincoln (2005) argued that qualitative methods aim to gather in-depth knowledge of consumer behaviors. Qualitative methods provide detailed results that offer many ideas and concepts to inform the program (Merriam, 2009). This method mainly focuses in investigating why and how to make decision. Smaller, but focused samples, are more often used than large samples. The most common tools used in qualitative market research are focus groups and individual in-depth interviews. In modern research, most psychologists tend to adopt a combination of qualitative and quantitative approaches. This ensures statistically-reliable information obtained from numerical measurement to be backed up as well as enriched by information about the research participants' explanations.

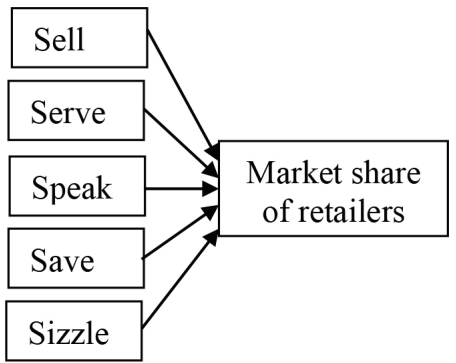

Figure 1: 5Ss affects

\subsection{Population and Sampling}

Local customers, managers, directors of retailers, and business competitors who are specialists in the field of e-marketing activities in Vietnam took part in this research. According to Cooper and Emory (1995), sampling refers to selecting elements of a population so conclusions may be generalized to the entire population. In this study, the researchers collected information from customers, managers, and directors of 25 retailers in Vietnam. In each retailer, the researcher delivered survey questionnaire to 15 people who are customers, managers and directors. The total number of survey questionnaires delivered is 375 , and 360 survey questionnaire were collected. Among these, 345 were accepted, with 15 survey questionnaires not accepted because of wrong choice to some items. The respondents are both female and male.

\subsection{Data Instrument Collection}

\subsubsection{Qualitative Method: In-Depth Interview}

The researcher first conducted an in-depth interview with managers, directors and customers of retailers in Vietnam to discover and explore the critical factors of e-marketing affecting the market share of retailers. Among them are three customers and two managers and directors.

\subsubsection{Quantitative Method: Survey Questionnaire}

The survey questionnaire consists of two main parts: personal information and benefits of e-marketing implementation used by retailer. Part 1 related to personal information such as age group, gender, job title, and level of education. Part 2 related to 5Ss model of e-marketing, which consists of Sell, Serve, Speak, Save, and Sizzle. Each component included smaller items aiming to get more data for the research. All items in the survey questionnaire are based on the five dimensions mentioned clearly in 5Ss e-marketing model. There are 23 smaller items in the 5Ss E-marketing model. For these parts, respondents answer the English-language survey questionnaire on a 5-point Likert scale 1 to 5 ('strongly disagree' to 'strongly agree'). 


\subsection{Validity and Reliability}

Reliability: According to Cronbach (1946), the coefficient alpha assesses the reliability of multipoint-scale items. The higher the coefficients, the better the measuring instrument. Cronbach (1946) also argued that the coefficient should be 0.7 or higher. In this research, Cronbach's Alpha was calculated for Sell, Serve, Speak, Save and Sizzle of e-marketing activities.

Validity: The validity was set up with the assistance and support of the key managers and directors from retailers in Vietnam who commented on content, construct, measurement and format of questionnaire and passed judgment on the suitability of the items chosen before conducting the survey. In order to develop the questionnaire, a pilot survey was conducted by delivering survey questionnaires to managers, directors and customers of five different retailers in Vietnam.

\subsection{Data Analysis Procedure}

The researcher used the SPSS 16.0 software to analyze the data collected from the survey questionnaire and in-depth interviews to test the hypothesis and the overall framework of the research. SPSS 16.0 was used as following: (1) Descriptive statistical analysis - it help understand and master the features and characteristics of dependent and independent variables. (2) Factor analysis - both dependent and independent variables were analyzed to identify the underlying variables, and which the correlations between items and factors were calculated. (3) Reliability analysis - every single factor was tested for reliability to ensure the internal consistency of each variable. Reliability refers to the internal consistency of items that measure a latent construct. Internally-consistent items form a homogeneous set in that they vary together statistically. Reliability was measured by Cronbach's Alpha coefficient (Cronbach, 1951).

\section{Research Results}

\subsection{Descriptive Statistics}

In-depth interview: the sample size of the interview consisted of 50 people. Among these 50 respondents, 30 were customers, and 20 were managers and directors. For the age group, more than half of the interviewees were between 30 and 40 years old, representing $54 \%$ of the whole interview group. Of all 50 interviewees, 29 are female making up 58\%. For the qualification of the respondents, more than half of them got college or university degree (62\%) and six people got higher education degree (Master or PhD). Official survey: the sample size of the survey was 375. 345 questionnaires were collected, accounting for $92 \%$. All questionnaires are valid for the analysis.

\subsection{Measurement}

The 23 items of the survey questionnaire are shown in Table 1 representing the outcome of the descriptive analysis. Means of 23 items ranged from 3.3733 to 4.3533 . The lowest mean is that of the item "Increase interaction with different content" and the highest mean is that of the item "Grow your sales".

The central tendency with means calculation and the measure of dispersion with standard deviation calculation were done for five constructs: Sell, Serve, Speak, Save and Sizzle. Sell variable of the e-marketing strategy is assessed highest, with a mean of 3.9667 , all items measured 3.4333 and above. The lowest mean was that of the item "Sell more products" and the performance of the "Grow your sales" is perceived highest (4.3533).

The total mean of Serve was lower than that of Speak variable (3.7668). Among the four small items of Serve, the "Increase interaction with different content" is assessed lowest, with a mean of 3.3733. The total mean of Speak variable is 3.8507. In the five items of Speak, the item "Get closer to your customers" is evaluated lowest, with the mean of 3.62. The Save in E-Marketing strategy is perceived as the lowest mean in five constructs with the mean of 3.6613. There were no items higher than 3.8467, out of which the "Reduce printing cost" is assessed lowest (3.44). The total mean of Sizzle in e-marketing strategy is 3.8250 . In four items of the Sizzle construct, the "Improve brand awareness" as the lowest mean (3.78), then the Extend the market (3.7933).

\subsection{Reliability}

Cronbach's Alpha is a statistical test used to examine the correlation between variables. There are two related aspects related, which are the relationship between the variables themselves and the correlation of the scores of each variable with a score of all the variables of each response. This method allows the removal of the unsuitable variables and spam variables in the model. Accordingly, only those variables with Cronbach's Alpha greater than 0.6 are accepted and appropriate for data to be included in the next step.

Table 2 shows Cronbach's Alpha for each variable of Sell, Serve, Speak, Save and Sizzle. For the Serve and Sizzle variables, since all the Cronbach's Alpha are greater than 0.6, and since the deleted items make not much difference, all factors and variables are accepted. In the Sell variable, the researcher found that, with deleted Sel5, the Cronbach's Alpha is be higher at .757. As well as Speak and Save variables, the Cronbach's Alpha is .708 and .779, respectively, with Spe5 and Sav3 deleted. To get a higher Cronbach's Alpha coefficient, the researcher decides to remove Sel5 "More audience can visit web shop", Spe5 "Also through website", and Sav3 "Reduce printing cost". 
Table 1: Descriptive statistics

\begin{tabular}{|c|c|c|c|}
\hline Variables & $\mathbf{N}$ & Mean & $\begin{array}{c}\text { Std. } \\
\text { Deviation }\end{array}$ \\
\hline $\begin{array}{l}\text { Sel1. Target a broader } \\
\text { audience through online } \\
\text { marketing }\end{array}$ & 345 & 4.2733 & .64399 \\
\hline Sel2. Grow your sales & 345 & 4.3533 & .75206 \\
\hline Sel3. Show more products & 345 & 3.8667 & .70155 \\
\hline Sel4. Sell more products & 345 & 3.4333 & .78933 \\
\hline $\begin{array}{l}\text { Sel5. More audience can } \\
\text { visit web shop }\end{array}$ & 345 & 3.9067 & .66903 \\
\hline $\begin{array}{l}\text { Ser1. Create additional } \\
\text { benefits }\end{array}$ & 345 & 3.9467 & .54078 \\
\hline $\begin{array}{l}\text { Ser2. Faster customer } \\
\text { service }\end{array}$ & 345 & 3.9067 & .57167 \\
\hline $\begin{array}{l}\text { Ser3. Serve more } \\
\text { customers }\end{array}$ & 345 & 3.8400 & .54440 \\
\hline $\begin{array}{l}\text { Ser4. Increase interaction } \\
\text { with different content }\end{array}$ & 345 & 3.3733 & .60807 \\
\hline $\begin{array}{l}\text { Spe1. Providing content } \\
\text { that can be accessed from } \\
\text { work }\end{array}$ & 345 & 3.9267 & .84422 \\
\hline $\begin{array}{l}\text { Spe2. Providing content } \\
\text { that can be accessed from } \\
\text { home }\end{array}$ & 345 & 4.0933 & .71744 \\
\hline $\begin{array}{l}\text { Spe3. Skype, yahoo, or } \\
\text { email will help }\end{array}$ & 345 & 3.9333 & .62031 \\
\hline $\begin{array}{l}\text { Spe4. Get closer to your } \\
\text { customers }\end{array}$ & 345 & 3.6200 & .75680 \\
\hline Spe5. Also through website & 345 & 3.6800 & .92192 \\
\hline $\begin{array}{l}\text { Sav1. Reduce cost for } \\
\text { employee fee }\end{array}$ & 345 & 3.8467 & .85716 \\
\hline Sav2. Reduce postage cost & 345 & 3.5867 & .73445 \\
\hline Sav3. Reduce printing cost & 345 & 3.4400 & .61829 \\
\hline Sav4. Save time & 345 & 3.7200 & .70587 \\
\hline $\begin{array}{l}\text { Sav5. Increase web self - } \\
\text { service }\end{array}$ & 345 & 3.7133 & .93648 \\
\hline $\begin{array}{l}\text { Siz1. Improve brand } \\
\text { awareness }\end{array}$ & 345 & 3.7800 & .74067 \\
\hline $\begin{array}{l}\text { Siz2. Provide the new } \\
\text { proposition }\end{array}$ & 345 & 3.8533 & .56028 \\
\hline Siz3. Gain more experience & 345 & 3.8733 & .57108 \\
\hline Siz4. Extend the market & 345 & 3.7933 & .55920 \\
\hline $\begin{array}{l}\text { Goal of implementing } \\
\text { E-Marketing is to Improve } \\
\text { Sales }\end{array}$ & 345 & 3.8533 & .69886 \\
\hline
\end{tabular}

Table 2: Cronbach's Alpha of Total-Item Statistics

\begin{tabular}{|c|c|}
\hline Variables & $\begin{array}{l}\text { Cronbach's Alpha } \\
\text { if Item Deleted }\end{array}$ \\
\hline Cronbach's Alpha of Sell & .702 \\
\hline $\begin{array}{l}\text { Sel1. Target a broader audience } \\
\text { through online marketing }\end{array}$ & .632 \\
\hline Sel2. Grow your sales & .610 \\
\hline Sel3. Show more products & .612 \\
\hline Sel4. Sell more products & .627 \\
\hline $\begin{array}{l}\text { Sel5. More audience can visit web } \\
\text { shop }\end{array}$ & .757 \\
\hline Cronbach's Alpha of Serve & .709 \\
\hline Ser1. Create additional benefits & .659 \\
\hline Ser2. Faster customer service & .608 \\
\hline Ser3. Serve more customers & .580 \\
\hline $\begin{array}{l}\text { Ser4. Increase interaction with } \\
\text { different content }\end{array}$ & .730 \\
\hline Cronbach's Alpha of Speak & .701 \\
\hline $\begin{array}{l}\text { Spe1. Providing content that can be } \\
\text { accessed from work }\end{array}$ & .620 \\
\hline $\begin{array}{l}\text { Spe2. Providing content that can be } \\
\text { accessed from home }\end{array}$ & .591 \\
\hline $\begin{array}{l}\text { Spe3. Skype, yahoo, or email will } \\
\text { help }\end{array}$ & .672 \\
\hline Spe4. Get closer to your customers & .664 \\
\hline Spe5. Also through website & .708 \\
\hline Cronbach's Alpha of Save & .701 \\
\hline Sav1. Reduce cost for employee fee & .719 \\
\hline Sav2. Reduce postage cost & .691 \\
\hline Sav3. Reduce printing cost & .779 \\
\hline Sav4. Save time & .730 \\
\hline Sav5. Increase web self - service & 677 \\
\hline Cronbach's Alpha of Sizzle & .885 \\
\hline Siz1. Improve brand awareness & .829 \\
\hline Siz2. Provide the new proposition & .835 \\
\hline Siz3. Gain more experience & .851 \\
\hline Siz4. Extend the market & .887 \\
\hline $\begin{array}{l}\text { Goal of implementing E-Marketing is } \\
\text { to Improve Sales }\end{array}$ & .705 \\
\hline
\end{tabular}


Table 3: Cronbach's Alpha of Five Constructs

\begin{tabular}{|l|c|c|}
\hline Variables & $\begin{array}{c}\text { Cronbach's } \\
\text { Alpha }\end{array}$ & N of Items \\
\hline Sell & .757 & 4 \\
\hline Serve & .709 & 4 \\
\hline Speak & .708 & 4 \\
\hline Save & .779 & 4 \\
\hline Sizzle & .885 & 4 \\
\hline Total & .705 & 20 \\
\hline
\end{tabular}

\section{Implications}

Technology enhancement for full message delivery: Although a big and dramatic change in term of technology has been observed, especially related to informatics or high technology, the application of e-marketing that could provide the fast speed of processing and security in transaction remains a question for most business owners. Besides, the habit of dealing with shopping channels via traditional market (usually wet or open market) still exists and a proportion of housewives going shopping online is limited. Although there has been great achievement, the national information systems and infrastructure are still unable to provide an efficient network for promoting online shopping or services, among which e-commerce is quite a big issue.

According to international experts, Vietnam's IT has lagged behind the region for several decades. While Thailand and Indonesia have nearly 200 Internet service providers (ISPs) and the number in Malaysia has reached 100, Vietnam only possesses very few. Nevertheless, it could be seen that after the process of renovation, Vietnam has successfully implemented its modernization and speeding strategy in the Information and Communication Technology industry, achieving great progress in terms of technology and service development. So far in 2018, Vietnam forcefully adjusted its strategy to meet its new goals for the development of Information Community Technology in the country as a whole (see Figure 2).

The most important thing to keep in mind when conducting Internet marketing is the technology. While interacting with customers indirectly, the color and all illustration and display should be cared for to ensure the message is delivered fully and completely in the most convenient and understandable way. Therefore, to overcome the problems of display and interaction with customers, especially to increase the competitiveness and gain market share against foreign competitors, retailers should take into consideration building an excellent technology via agencies.

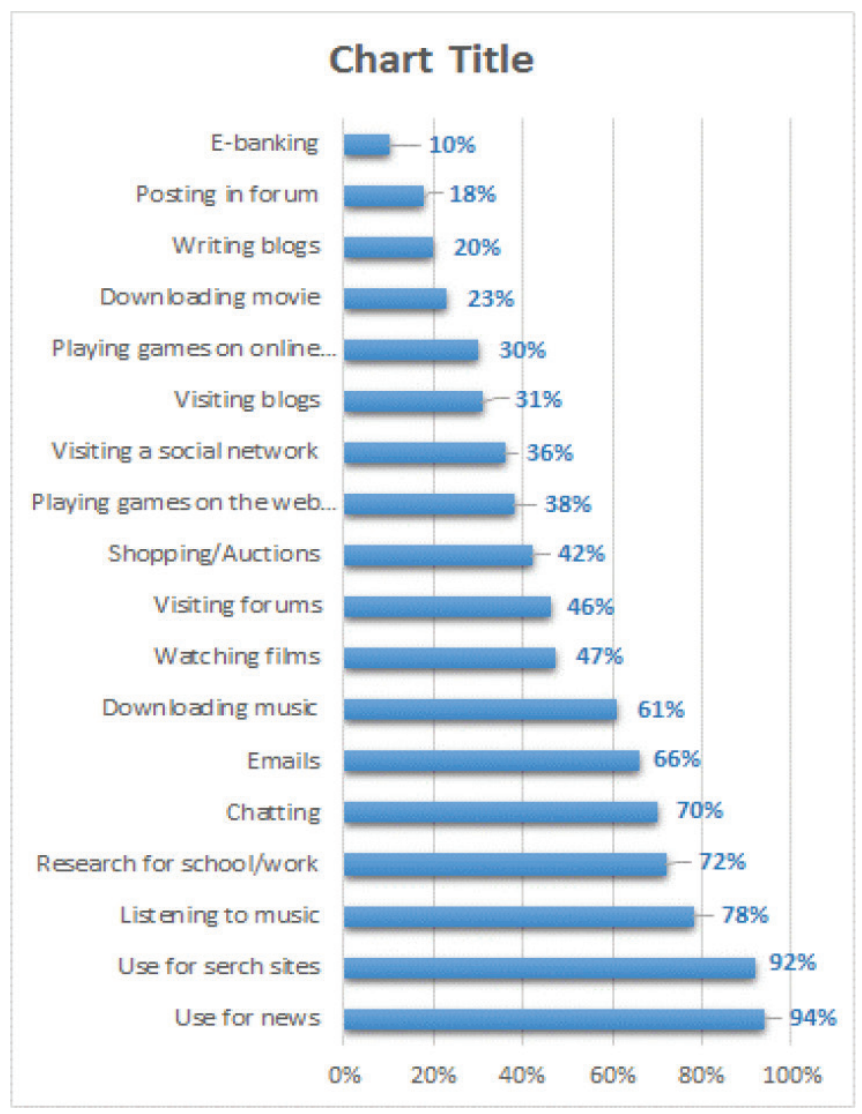

Figure 2: Internet users' purposes

Approaching target customers: The research reveals that about $80 \%$ of Vietnamese consumers believe in advertisements, but this percentage has kept on decreasing as time passes. Although the number of Internet users increases every year, most users now do it with purposes (Cimigo NetCitizen, 2016). It can be seen that online shopping has not been familiar to Vietnamese buyers and the task of deploying e-marketing should start with educating customers about the convenience and exciting experience of online shopping. This will in turn increase the visits of shoppers to retailer websites and helps enhance the brand awareness and preference. The use of pop-up tools and e-mail marketing could be taken into consideration in this case. Pop-up advertisement could easily attract customer's attention through its high interactive level and beautiful display plus the widespread impacts of e-mail marketing; the results could be impressive within a short period of time.

Improvement of product diversity: The advantage of modern trade over traditional trade is its diversification of products. Especially in this case, where retailers would like to make use of e-marketing to target a larger portion of customers, they should pay more attention to product 
diversity. There are three primary reasons for this. First, while shopping online, customers are rarely impacted by displays like what they are exposed to in supermarkets, and so far there is rarely any modern trade channel in Vietnam providing online shoppers with such satisfactory visual experience. Thus, retailers should make sure to deliver the message of product diversity to their customers. Basically, shoppers are individual customers, they tend to switch easily from one supplier to another. If there is any chance their needs could not be satisfied, a retailer will lose its customers leading to the drop in sales and market share. Besides, e-marketing with its tools and engines could use pop-up advertisements to notify visitors of the wide range of products available. Also, by linking to the most popular websites or fora designed for housewives or online shoppers and search engines, retailers could also spread the brand and convenience.

\section{References}

Baker, M. J. (2007). The marketing book (5 $5^{\text {th }}$ ed.). Oxford: UK: Butterworth-Heinemann.

Booms, B. H., \& Bitner, J. E. B. (1981). Marketing strategies and organizational structures for service firms. In: J. Donnelly \& W.R. George (Eds), Marketing of services. Chicago, IL: American Marketing Association.

Brown, B. C. (2006). How to use the Internet to advertise, promote and market your business or Web site- with little or no money. Ocala, FL: Atlantic Publishing Company.

Chaffey D., \& Paul, S. (2008). E-Marketing Excellence: Planning and Optimizing Your Digital Marketing, ( $3^{\text {rd }}$ ed.). Chartered Institute of Marketing. Oxford: UK: Butterworth-Heinemann.

Chaffey, D., \& Smith, P. R. (2005). E-Marketing excellence: The heart of eBusiness (2nd ed.). Oxford, UK: Elsevier ButterworthHeinemann.

Chaffey, D., Ellis-Chadwick, F., Johnston, K., \& Mayer, R. (2006). Internet marketing: Strategy, Implementation and Practice (3rd ed.). Harlow, UK: Pearson Education Limited.

Cooper, D. R., \& Emory, C. W. (1995). Business Research Methods ( $5^{\text {th }}$ ed.). Homewood, IL: Richard D. Irwin, Inc.

Cooper, D. R., \& Schindler, P. S. (2006). Business Research Methods (9th ed.). New York, NY: MacGraw-Hill.

Cronbach, L. J. (1946). Response sets and test validity. Educational \& Psychological Measurement, 6, 475-494

Deming W. E. (1960). Sample Design in Business Research. New York, NY: John Wiley \& Sons.

Dinh, H., \& Doan, T. H. (2020). The Impact of Senders' Identity to the Acceptance of Electronic Word-of-Mouth of Consumers in Vietnam. Journal of Asian Finance, Economics and Business, 7(2), 213-219. https://doi.org/10.13106/jafeb.2020.vol7.no2.213
Firman, A., Putra, A. H. P. K., Mustapa, Z., Ilyas, G. B., Karim, K. (2020). Re-conceptualization of Business Model for Marketing Nowadays: Theory and Implications. Journal of Asian Finance, Economics and Business, 7(7), 279-291. https://doi. org/10.13106/jafeb.2020.vol7.no7.279

Giao, H. N. K (2020). Customer Satisfaction at Tiki.vn E-Commerce Platform. Journal of Asian Finance, Economics and Business, 7(4), 73-183.

Ivan, S., \& Dragan, V. (2003). The 4 Pillars Internet marketing Strategy. Retrieved from: http://www.ipowerstrategy.com.

Khoa, B. T. (2020). The Antecedents of Relationship Marketing and Customer Loyalty: A Case of the Designed Fashion Product. Journal of Asian Finance, Economics and Business, 7(2), 195204. https://doi.org/10.13106/jafeb.2020.vol7.no2.195

Kotler, P. (2003). Marketing Essentials. Evanston, Illinois, Northwestern University

Kuhn, T. S. (1961). The Function of Measurement in Modern Physical Science. ISIS, 52(2), 161-193.

Laudon, K. C., \& Traver, C. V. (2010). E-Commerce (7th ed.). Upper Saddle River, NJ: Prentice Hall.

Merriam, S. (2009). Qualitative research: A guide to design and implementation. San Francisco, CA: Jossey-Bass.

Mohammed, R., Robert J. F., Bernard J. J., \& Paddison, G. (2003). Internet marketing ( $2^{\text {nd }}$ ed.). New York, NY: McGraw-Hill

Moran, M., \& Hunt, B. (2006). Search engine marketing, Inc: driving search traffic to your company's web site. London, UK: Pearson Education.

Nguyen, O. T. (2020). Factors Affecting the Intention to Use Digital Banking in Vietnam. Journal of Asian Finance, Economics and Business, 7(3), 303-310. https://doi.org/10.13106/jafeb.2020. vol7.no3.303

Rhee, Y. (2004). An Overview of Public Relations Theory. College Park, University of Maryland.

Smith, P., Berry, C., \& Pulford, A. (1999). Strategic marketing communications: new ways to build and integrate communications. London, UK: Kogan Page Publishers.

Smith, P. R., \& Chaffey, D. (2005). E-Marketing excellence: at the heart of e-Business (2nd ed.). Oxford, UK: Butterworth Heinemann.

Tabash, M. I, Albugami, M. A., Salim, M., \& Akhtar, A. (2019). Service Quality Dimensions of E-retailing of Islamic Banks and Its Impact on Customer Satisfaction: An Empirical Investigation of Kingdom of Saudi Arabia. Journal of Asian Finance, Economics and Business, 6(3), 225-234. https://doi. org/10.13106/jafeb.2019.vol6.no3.225

Tham, K. W., Dastane, O., Johari, Z., \& Ismail, N. B. (2019). Perceived Risk Factors Affecting Consumers' Online Shopping Behaviour. Journal of Asian Finance, Economics and Business, 6(4), 246-260. https://doi.org/10.13106/jafeb.2019.vol6.no4.249 